This article was downloaded by: [University of Alberta] On: 23 November 2014, At: 17:40

Publisher: Routledge

Informa Ltd Registered in England and Wales Registered Number: 1072954 Registered office: Mortimer House, 37-41 Mortimer Street, London W1T 3J H, UK

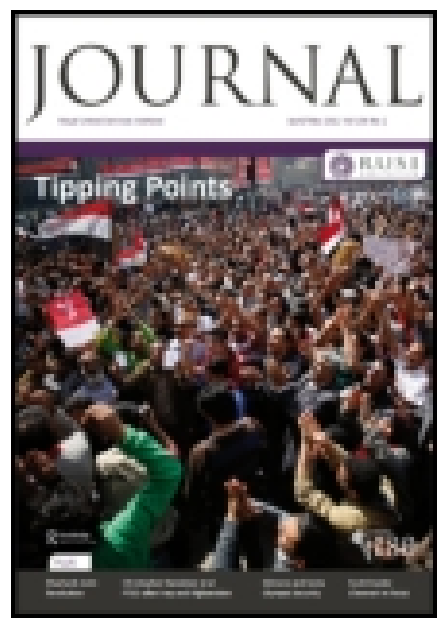

Royal United Services Institution. J ournal

Publication details, including instructions for authors and subscription information: http:// www. tandfonline.com/ loi/rusi 19

\title{
Ancient Naval Tactics. Part I
}

Rev. Edmond Warre M.A.

Published online: 11 Sep 2009.

To cite this article: Rev. Edmond Warre M.A. (1876) Ancient Naval Tactics. Part I, Royal United Services Institution. J ournal, 20:88, 593-607, DOI: 10.1080/03071849709416324

To link to this article: http:/ /

dx. doi.org/ 10.1080/03071849709416324

\section{PLEASE SCROLL DOWN FOR ARTICLE}

Taylor \& Francis makes every effort to ensure the accuracy of all the information (the "Content") contained in the publications on our platform. However, Taylor \& Francis, our agents, and our licensors make no representations or warranties whatsoever as to the accuracy, completeness, or suitability for any purpose of the Content. Any opinions and views expressed in this publication are the opinions and views of the authors, and are not the views of or endorsed by Taylor \& Francis. The accuracy of the Content 
should not be relied upon and should be independently verified with primary sources of information. Taylor and Francis shall not be liable for any losses, actions, claims, proceedings, demands, costs, expenses, damages, and other liabilities whatsoever or howsoever caused arising directly or indirectly in connection with, in relation to or arising out of the use of the Content.

This article may be used for research, teaching, and private study purposes. Any substantial or systematic reproduction, redistribution, reselling, loan, sub-licensing, systematic supply, or distribution in any form to anyone is expressly forbidden. Terms \& Conditions of access and use can be found at http://www.tandfonline.com/page/terms-andconditions 


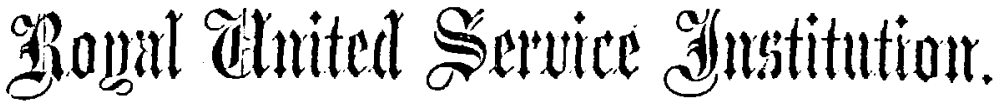

VoL. XX.

1876.

No. LXXXVIII.

\section{LECTURE.}

Friday, 7th April, 1876.

ReAr-Adural T. A. B. SPRATT, C.B., F.R.S., in the Chair.

ANCIENT NAVAL TACTICS.

ParT I.

By the Rer. Edxoxd Warre, M..A., Eton College.

I canor help feeling that at the rery outset of this lecture an apology is due on my part for venturing to address an audience in the theatre of this Institution npon the very difficult, though interesting, subject of ancient naval tactics. For, in order that such a themo may bo properly handled, three things are requisite: 1st, elassical knowledgo; 2ndly, a practical acquaintance with seamanship and naval construction; 3rdly, leisure; and of these three the two latter have fallen to my lot in but very scanty proportions. Hence the sketch that I am about to offer you will present many imperfections and omissions both to scholars and to nautical men; but the time that has been spent upon it will not have been wholly unfruitful, if by it, perchance, some member of the illustrious naval profession, who may liappen to have both learning and leisure at his command, shall be induced to study this question, and throw light upon its many obscurities.

The subject before us is that of "Ancient Naval Tactics;" but, haring regard to its vastness and complexity, it will be as well at once to introduce some limitations, so that we may not attempt an impossiblo task in sixty minutes. By ancient, therefore, wo will understand Grcek and Roman-dismissing altogether those interesting questions concerning the Assyrian, Phonician, Egsptian, and Carthaginian navics, which might well form the subject of a separate discourse. Of the Grceks and Romans we shall find ourselves compelled to give most attention to the former, not only as presenting us rith the best information, but as being in virtue of their seafaring habits, their constructive skill, and their tactical intelligence, facile principes in the naval art.

With these limitations, the consideration of ancient naval tactics will. in the first place, involve an inquiry into the character of the principal tactical units of which an ancient fleet was composed, their gradual development, their construetion, and propulsion. Secondly, we shall find ourselres called to notice the weapons of offence with which these tactical units were armed, and especially the ram which has, owing to voc. $x x$. 
recent developments, a peculiar claim upon our attention. Thirdly, we shall come to tactics proper; minor tactics, as exhibited in the handling of a single vessel, and grand tactics, as illustrated by such instances as we lave of the disposition and mancourring of fleets. Instly, we may draw a comparison between the fleets of ancient and modern times, their tonnage, their power of propulsion, and the number of men employed.

Of these divisions of the subject, the first will more than occupy our time to-day; but I trust, through the kindness of the Conncil, that I may hare an opportunity of dealing with the remainder at no very distant date.

'The subject of ancient galleys is one which, as is well known, has a literature of its own. We can but briefly glance at this. A mere enumeration of the names of the authors who have expended their toil and their acumen upon it would cost us too long. The first, who, after the revival of letters undertook a treatise "de re Navali," was the Ambassador at Venice of the French king Francis the First, the Chevalier de Baif. No donbt, the sight of the grand galleys that thronged the blue waters of the Qneen of the Adriatic suggested this work to him; but it also started him with prejudices as regards form and construction which made him labour to prove that impossible which the clear testimony of the ancients undoubtedly affirms. Once introduced to literate Europe, the subject, owing to its interesting character and obvious perplexities, became a favourite with the learned, and we find many great names atfached to treatises upon it. Our own Sir Henry Savile, Provost of Eton, the great Scaliger, Scheifer of. Upsala, ILeibom of Amsterdam, and Isaac Fossius, are among those who, in the seventeently century, entered the lists of the literary tournament "de re Narali." Of all these it may be said with truth that while each in his turn criticised the fanlts of his predecessors he fell into errors no less grent himself; not, indeed, in most cases from want of learning, or of industry, or of literary insight, but chiefly because the data dealt with were insufficient, and the whole approached from the theoretical and not from the practical side.

During the last century, and indeed up to the last twenty jears, Scheffer's trentise "de re Militari Navali" remained the best text book on the subject. Montfaucon in his "L'Antiquité Expliqnée" gires some illustrations from the colnmn of Trajan and the church of San Lorenzo, two of which have been enlarged for this lecture. With this exception there is nothing concerning our subject in the last century that calls for notice, except the ingenious and practical attempt of a countryman of onr orn, General Melvill, who caused, in the year 1773, a model of a quinquereme to be erected against a high wall behind his house in Pulteney Street, in which we are told that he "performed the motions of rowing with some Officers of both the iand and sea service, and all agreed, as well as one of His Majesty's chief ship-builders, who had come to inspect it, that such and no other must have been the construction of the areient galleys." Though we cannot quite eudorse this opinion, since tha side of the quinquereme in question appears to have been at a very 
improbable angle $\left(45^{\circ}\right)$ to the water, yct we may say that the gallant General's attempt was certainly the most successful of those that hava hitherto been made. In the present century Mr. Joln Howell, about the year 1826, constructed a trireme for the Edinburgh Society of Antiquaries. Of late jears the subject has been liandled with ability by Mr. Smith of Jordan Hill, whose solution, however, is found to conflict with the eridence of antiquity; and with plausibility by M. Jal, the author of the "Glossaire Nautique," and of two rolumes on "Archéologie Navale." MI. Jal's knowledge of medioral shipping renders both these works extremely valuable, but his imperfect knowledge of Greek and Latin makes his conjectures as to ancient galleys misleading. It is very unfortunate that the trireme constructed at Paris by the order of the late Emperor Napoleon, under the superintendence of the very eminent naval architect M. Dupay de Lôme, should have been built in accordance with the ideas of one whose interpretations of the ancient authors are at fault.

The honour of having solred many, if not most of the difficalties which hare perplexed so many eminent men, must be given to the illastrions German scholar Boeckl, and his pupil Dr. Graser, who in an exhaustive treatise "de re Navali" has elncidated satisfactorily the most knotty points of this ancient problem. The discovery at Athens in the year 1834 of a number of inseriptions which proved to be inrentories of galleys and their gear, belonging to the dockyard at the Peireus, dating from a period not long subsequent to the close of the Peloponnesian War, was an erent of the utmost importance in the history of our subject. These authentic documents of the Athenian Admiralty, when elucidated by the vast erudition and great critical ability of the author of the "Public Economy of Athens," and by the practical sagacity and geunine enthnsiasm of his learned pupil Graser, hare shed a flood of light upon the whole question of the construction of ancient ships of war.

Would it be out of place here to express a hope that as we have now the data upon which such a work could be undertaken with a prospect of success, funds and enthusiasm may be forthcoming now as they were a hundred years ago, and another attempt be made to reproduce the Attic trireme as it was in the days of Phormion or of Chabrias?

But we must hasten on to describe such a trireme, premising that we shall find bat little help in the representations that remain to us on the coins, pottery, bas-reliefs, or pictures of antiquity. In the case of coins the scale is so small that but little can be gathered as to detail, though this field is not altogether barren with regard to the comparison of types of vessels of different epochs and localities. In the other representations the treatment is for the most part so conventional, and so deroid of perspective that bat a few things can be learnt. The artist has generally been, as in the case of the representations on the column of Trajan, anxious solely to pourtray the figures of men and animals to advantage, the accessories, whether ships or houses, being treated in an arbitrary manner, and dwarfed out of all proportion. Still these representations are interesting as pre$2 \mathrm{R} 2$ 
serving certain records of detail, and we shall find them useful for reference from time to time.

It is important to observe that the ancient ship of war was an improvement on the pirate vessel, just as the piratical craft itself was an improvement on the original merchant galley, and made with a view to superior speed and handiness. The trader, built to carry goods, was broad of beam and slow of speed, and gradually, as heavier weights were to be transported, ceased to depend upon oars, and trusted to sails for locomotion. The predatory instincts of mankind were not slow to equip themselves with craft fitted so as to be speedy enough to overtake the sluggish merchant-man, and at the same time roomy euough to stow away their ill-gotten gains. Not that in early times such gains were looked upon as ill. gotten. T'he Robin Hoods of the sea, whom we should deem cutthroat villains, were merry gentlemen in their own estimation, and in that of their neighbours, bold buccancers, who were not ashamed of their profession. But the fact that they were enemies of cirilisation was also patent, and the necessity of putting them down became more manifest as the advantages of commerce and free maritime interconrse were more generally appreciated. The mythological eleva. tion to the judicial bench in the infernal regions of Minos, King of Crete, had perhaps, if we may renture a conjecture on such a subject, its origin in the stern justice with which that monarch repressed piracy, and the sense of the benefit that resulted to mankind from his efforts. Ho is mentioned by Thucydides as the first possessor of a fleet in Greek waters, and the historian tells us that he used it in establishing his Thalassocracy, or maritime dominion, by putting down the pirates. To this end, and thus early was the Greek ship of war elaborated. It is easy to see that the point in which it would bo made to excel its pirate foes would be swiftness, and that this swiftness would be attained by constrnction with a riew to carrying nothing but the crew and the necessary provisions and armament. Hence the ship of war was known as the "long ship" par excellence. Centuries, however, were necessary to perfect its construction. The ships of the Homeric period, long after Minos, were still undecked, except at the bow and stern, where they had fighting decks. We hear nothing in Homer of the ram, or of the distinction between rowers and seamen and marines, which is so marked at a later period.

In the simpler early ressel any increase in the number of oars necessitated an increase in the length of the ship, till at last a limit was reached, when a loss of liandiness in turning outweighed the possible adrantage of increased specd. Hence the inrention of banks of oars; an invention by which the necessary distance of the "interscalmium," or space between the rowers' benches could be subdivided and utilised in such a manner that the oars might be doubled or trebled in number within the same horizontal space, and yet not clash together when worked in time. In order to comprehend better the prineiple upon which this improvement was effected, it must be understood from the first that, so far as we know, the ancients never, at any rate until late Roman times, employed more 
Soumal R V.S.Institution.

$\angle$ VOL 20.

EARLY GREEK VESSELS.

From Ftrusian Vase in the British Hustum. Date 700.60. B.C.
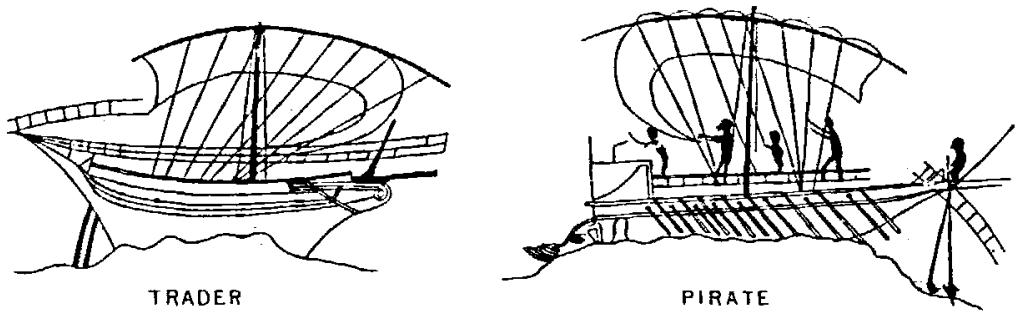

TRADER

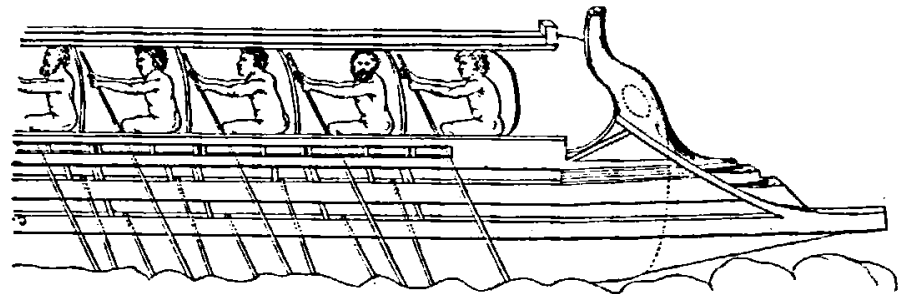

POSITION OF ROWERS
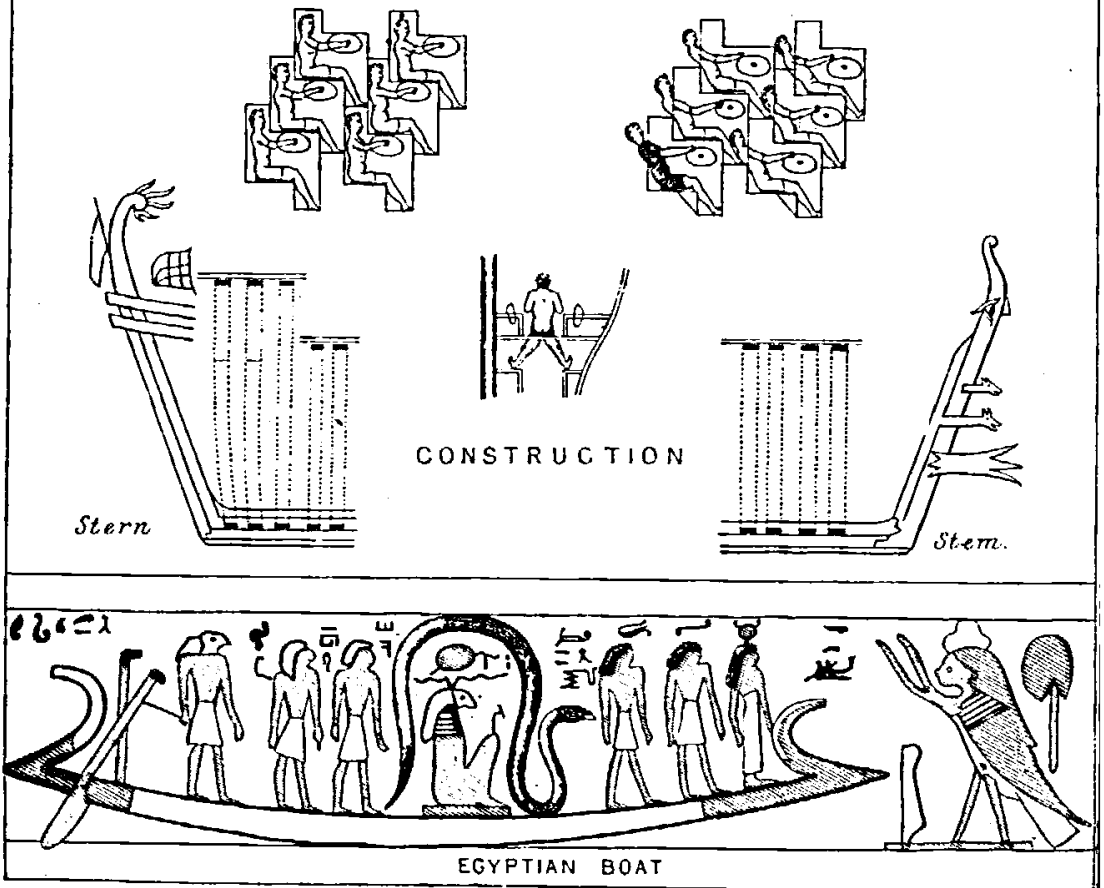

J.John!:: 
than one man to an oar. The construction of the Venetian gallegs,whether "alla scaloccio," in which long handled oars were worked by a number of men placed on successive steps rising inboard towards the centre of the vessel, or "alla zenzile," in which the space of the interscalmium was subdivided by oars with handles of different lengths, so that the rower of the longest oar sat nearer amidship than his neighbour - was unknown to the ancients. - Nor would it have suited their requirements in the long ships which had but a narrow space along the centre of the ressel, which they could not afford to lose. Accordingly, we find first among ancient slips single-banked galleys of $20,30,50$; and up to 100 oars each, in which the usual interscalminm of two cubits gives us a conjectural ground for estimating their length. These are all embraced under the term of "moneres," or " monocrota," as striking the water with one beat. The first improvement upon this was the construction of the bireme which if we are to believe Pliny, is due to the Erythræans, Ionian Colonists of Asia Minor. If anything is to be inferred from this, it is that the first step in the improvement of the construction of galleys came from the enstern and not the western side of the Azrean, and in all probability was of Phœnician origin. "Oe n'est que le premier pas qui coute," is a familiar and true proverb, and the invention does not deserve the slight notice which has been taken of it in ancient authors. When once the principle upon which increased power could be obtained by increasing the number of oars without lengthening the ship was discorered, it was easy to develop it, and it is worthy of notice that though the biremes gave place to triremes in the serenth century before Christ they ultimately survived them, and in the serenth century after Christ were in use when such a thing as a trireme was hardly to be seen. In like manner they in turn disappeared while their predecessors, the monocrota, survired. But to this growth and decay and its analogy in modern time, we may hare to refer later on.

By whon the trireme was invented we know not. Probably by the Phoenicians, for there is a statement in the Stromata of Clement of Alexandria that the Sidonians were the inventors. All we are told by Thueydides is that the Corinthinns were the first who built triremes in Greece, and farther, that an eminent naral constructor of Corinth, Aminocles by name, did not confine his skill to the limits of his own country, but built four of these new ships-of-war for the Samians, of which erent he fixes the date at about 300 yenrs before the end of the Peloponnesian war, or about 700 B.C.

At this point we may proceed, taking Graser as our authority, to describe as briefly as possible, the priuciples of construction and propulsion in the case of the trireme and quinquereme, so that we may have some definite idea of the character of the ressels employed when we proceed to consider the naval tactics of the Greeks and Romans.

And first we must call attention to the fact that two classes of vessels appear to have been employed, distinguished by the name of "Aphiact," unfenced, or "Cataphract," fenced, according as the rowers of the upper tier were protected or exposed. Both classes were 
decked and floored, but the "Aphract" class carried their decks and flooring lower than the "Cataphract," so that in them the rowers of the upper tier were visible above the side of the vessel; this is distinctly' seen in the bireme and trireme, given by Montfaucon from the Column of Triajan.

We have also an instance of the transitional form between the two classes, in the fragment of a bas-relief of an Attic trireme of which a cast is to be seen in the British Museum, and of which a sketch after Michaelis is given here.

Yon will remember that the disposition of the banks of oars was the problem to be solved, and that the object of arranging the oars in banks was to economise horizontal space, thus obtaining an increase in the number of oars without having to lengthen the vessel. Now, the rowers of the upper tier were called, from the elevated bench on which they sat, Thuanite; those of the middle tier Zygito, from the zyga or benches, which, in the Aphract class of ressels, traversed the whole breadth of the ship and bore the deck; those of the lower tier Thalanitce, from the thalamus or chamber in which (below the zyga in the Aphract class) they plied their oar. These names remained the same for the upper, middle, and lower tiers, even when the invention of Cataphract ships with high decks and more banks of oars than three, had altered the conditions of construction. The Aphract ships had their flooring one foot below the water line and the deck five feet above it.

After the battle of Actium, which was won by the use of the light Liburnian birenes, which were Aphract, the Romans seem to have built most of their vessels after what was then considẹred the new, but was in reality the old fashion. Previous to that date, from the time of the invention by the Thasians of this system, all the larger vessels of war used by both Greeks and Romans were Cataphract.

In the Cataphract trireme, the space allowed for each oarsman was, according to Graser, eight square feet per man, and this propor. tion was observed in the larger vessels up to the octireme. In vessels with ten or more banks of oars the proportion allowed seems to hare been reduced to seven square fect per man. TVe know from a passage in Cicero that the space was so completely filled and so densely crowded, that there was not room for an additional man.

The rowers in all classes of banked ressels sat in the same rertical plane, the seats ascending in a line obliquely inclined towards the stern of the ressel. Thus in the trireme, the Thranite was nearest to the sterm of the set of three to which he belonged. Next behind and somewhat below him sat his Zygite, and behind and below the Zygite, the Thalamite. The vertical distance between the seats belonging to the same set was 2 feet, the horizontal distance 1 foot. The seat itself was from 9 to 12 inches broad. The lowest rank used the shortest oars, and the difference of the length of the oar in-board was provided for by the outward currature of the ship's side. The oar ports were vertically 1 foot 3 inches below the handle of the oar when the blade was just touching the water. The lowest or Thalamite oar ports were 3 feet above the water. The Zggite oar ports were $4 \frac{1}{4}$, the Thranite 


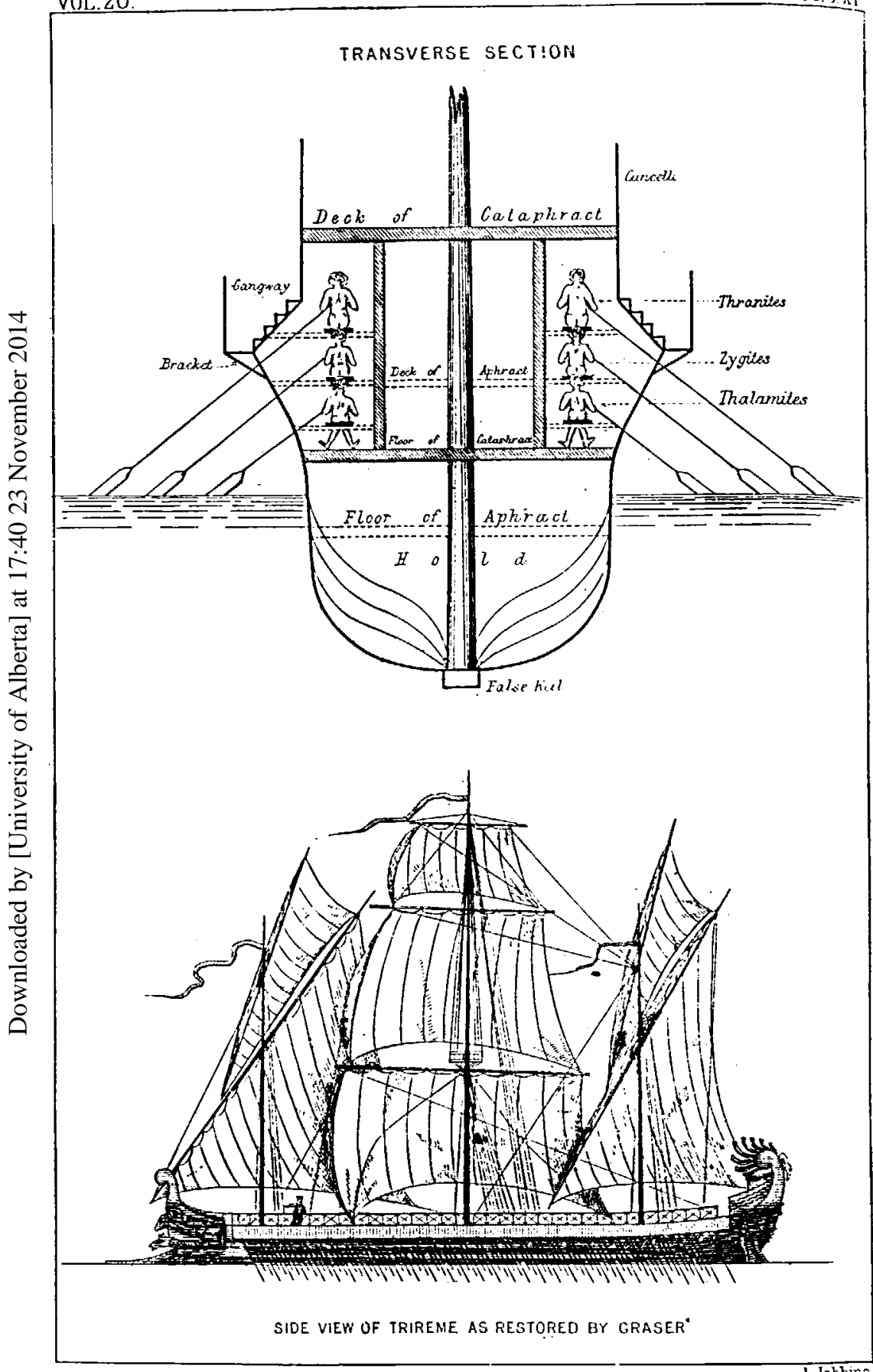


$5 \frac{1}{2}$ feet above the water. The vertical distance between the oar ports was but 15 inches, the distance obliquely measured on the ship's side 21 inches. Each oar port was protected by the ascoma or leather bag which fitted close over the oar, closing the aperture without impeding the action of the oar.

The seats of the rowers were supported on benches, three feet long, or thereabouts, which ran from the ship's side to beams which rose from the floor, and reached up to the under surface of the deck. These beams were inclined at an angle of $64^{\circ}$ towards the stern, and were at a distance of four feet apart. They were technically ealled the Diaphragma. This Diaphragma, viewed from inside the vessel, presented the appearance of a succession of staircases, the steps of which were the benches between it and the ship's side. The space between the Diaplragmata on either side constituted that part of the vessel in which stood the masts, and in which stowage was possible. It was in the Attic trireme seven feet wide. This arrangement is clearly shown by the model of a section of a Greek trireme which we have here, for which we are indebted to the intelligent and patient labour and constructive skill of a present Etonian, Dlr. Chambers.

The length of the oars used in the trireme has been calculated as follows. We know from the Attic tables the length of the oars used by the scamen or supernumerary oarsmen when there was need. These were the longest in the trireme, and they varied from 13 feet 6 inches to 14 feet 3 inches in length.

The Thranite oars must have been nearly of the same length, but could not have exceeded 14 feet under any cireumstances.

The Zygite oars were $10 \frac{2}{2}$ feet. The Thalamite $7 \frac{1}{2}$ feet.

The rowers where the space of eight square feet was allowed per man had a vertical space of 1 foot 3 inches allowed for the rise and depression of the handle in rowing, and a space horizontally of 2 feet $\hat{6}$ inches for its forward and backward motion. It is, however, probable that there was hardly any motion forward of the bods, the work being done by falling backwards from the perpendicular.

In all cases the uars used by the regular rowers preserved nearly the same proportion of one-third inboard to two-thirds outboard.

The oars of the upper ranks projected at the point where they reached the water 2 feet 6 inches beyond those of the next lowest tier.

In the case of the gigantic oars of the Tesseraconteres of Ptolemy, a vessel of the size of the "Agincourt," we are expressly informed that the handles were weighted with lead, so as to bring the oar inboard and outboard nearly to an equilibrium.

For the purposes of comparison I have appended a table showing the length of oars used in the different classes of ancient vessels, in the British Navy, and in the University and Eton eights.

Let us now proceed to consider the construction of the vessel itself. In the Cataphract class, the floor was 1 foot above the water-line. Below this was the hold which contained a certain amount of kallast, I'hrough the floor into the hold, the buckets for baling, or as $w$ 
should say the pumps, were worked, and that very constantly in ancient ressels, as the use of the word both by the poets and orators in meta. phors expressing labour and sorrow, amply attests.

The kecl (тpotıs) of the early ancient ship appears to have had consi. derable "camber." Under this was a strong false keel $\left(\chi^{\prime} \lambda_{v \sigma} \mu a\right)$, which was very necessary in ressels that had frequently to be drawn up on the shore. Above the keel was the kelson (ipvioxov, columba), into which the ends of the ribs were fastened. Abore the kelson lay the

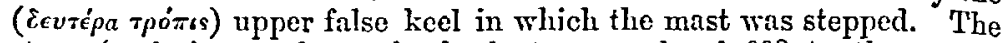
stem (oreipa) rase from the keel at an angle of $69^{\circ}$ to the water. Within was an apron ( $\phi^{\prime} \lambda \ll \iota s$ ) giving solidity to the bows which had to stand the weight of the beak and its concussion. The stem was carried upwards and cerred generally backwards abore the forecastle, termi-

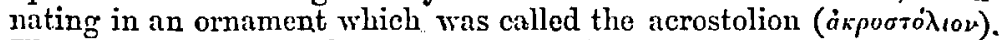
The sternpost rose at the same angle as the stem, and was carried high over the poop curving inwards, and finishing in the aplustre, an oma. ment which may be likened to the feathers on the head of an angry cockatoo; and behind this curred backwards the cheniscus or goose head, symbolising the floating powers of the vessel.

Ronnd the hull of the ressel horizontally at about the level of the

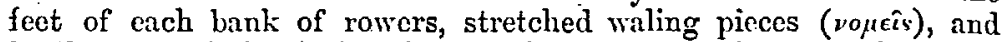
in the case of the Attic triremes, these were again strengthened by long cables (i:mołn'miza), which were bound round the ship from stem to stern, and which tightened by shrinking when wet, gave additional security to the ressel, which from her length and narrowness was apt to strain much in bad weather.

From the side of the ressel below the level of the thranitic bench projected the gangway (mápoiso, fori), for a space of 1 foot 6 inches, giving a passage of 3 feet in all. This was snpported by (B'a $\chi^{a} a$ ) brackets fitted below and springing from the ribs of the vessel. The gangway was fenced in by an upright bulwark extending the whole length of the space occupied in the ship by the rowers. Here, in the "Parodus," the (mepive!') seamen had their station in action as lightarmed troops; who also, when needed upon special occasions, rowed as supernumenry oarsmen with the long oars already mentioned.

The ribs of the ressel from the point where the bracket fitted to them, curved upwards and inwards to a height which was 10 inches above the heads of the thranitic oarsmen. Upon them at this height were placed the cross beams (orpwijpes), which supported the

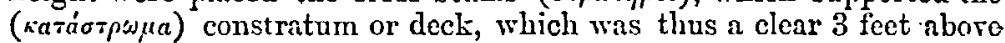
the gangway, allowing the marines (Em;Bazal) in action, free play for their javelins over the heads of the seamen in the Parodus.

Beyond the space occupied by the rowers, there was the Parexeiresin, a space of 11 feet in the bows and 14 feet at the stern, which included the (ik Hompric vessels. On either side of the main deck rose the cancelli, an open lattice work, and seen as such in the Aphract ships, but in the Cataphracts usually covered with hides, or with the (cilicium) goats hair curtains of that manufacture, at which St. Paul and Aquila and Priscilla used to labour working with their hands This served 
both as a protection against the wares and to a certain extent against the darts of the enemy.

At the bow and stern, toirers, especially in the Roman ressels, were often erected which gave a vantage height from which to shower down missiles on an enemy's deck.

In very early times we find the elevated forecastle, of which the very name is significant, and which, in some cases, strikingly reminds us of the structure erected at the bows of the "Derastation," serving to protect the fore deck from the waves, and the crew and marines from a raking fire as they approached the enemy,

On either side of the forecastle was figured the eye of the vessel, the centre of which was formed by an aperture which served as a hawsehole.

At the stern was a raised quarter-deck, on which was a hind of cabin or deck-house forming a shelter for the chief Officer and the helmsman. This quarter-deck was the sacred part of the ship. Here was the image of the patron god, not to be confased with the parasemon, or badge of the ressel figured near the bows. Behind the deckhouse rose the flag staff on which was hoisted the pennant (tenia) and probably in the caso of the admiral's ship, the red flag that was the signal for going into action, and such other signals as were from time to time required.

On either side the bows catheads ('iturices) projected, which in the case of the earlier Athenian triremes seem to have been merely sufficient to hold the anchor. The Corinthians, howerer, who, as we have seen, were enterprising and clever shipwrights, by strengthening greatly these catheads, were able to receive a blow from the enemy's ram in such a way as to inflict the damage they were intended to receive, an invention which cost the Athenians dear, both in the Corinthian Gulf and in the great harbour at Syracuse.

Between the catheads, and in front of the stem, projected two beams one above the other at some distance apart, headed generally with metal fashioned as a ram's head, or the head of some other animal,

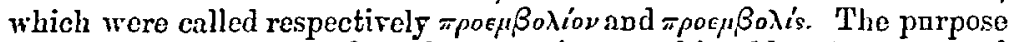
of these beams seems to have bcen to give a racking blow to any vessel pierced by the beak, which projected much further below, and thus to cause her to heel over and shake off, making it casier for the impinging ressel to disentangle herself by backing water.

Underneath was the rostrum or beak, answering to that which we now call the ram, which was a long spur, and in the later periods usually divided into three teeth. Of this we shall speat more fully hereafter.

The trireme was steered by two paddles or rudders, one on eilhar side of the stern of the vessel, to the tillers of which, under the deck, was attached a rope, which, passing through a block on cither side and over two wheels on the quarter-deck, enabled the helmsman to turn the two rudders which way he pleased by a single effort.

In the mid space of 7 feet, which we have already mentioned, as lying between the Diapliragmata, stood the main, or great mast, which was square rigged, and before aud behind it the two acati, fore mast 
and mizen mast, which carried lateen sails. The ancients, however, did not ase sails in action, trusting then entirely to their oars, so that I will not enter further into the question of the rigging.

We may now (for I fear that we are already surfeited with detail) briefly sum up the measurements of the trireme as calculated by Graser, so as to complete the picture of the vessel such as we may fairly imagine it to lave been.

The total length (exelusive of the beak, for which we must add nearly 10 feet), was 149 fect, of which 25 feet belong to the parexeiresix (11 to the bows and 14 to the stern) and 124 feet to the space occupied by the rowers.

The greatest breadth (which has been calculated in an ingenions manner from the thickness of the hawsers employed for anchoring the ressel, (a detail preserved to us in the Attic Tables) at the water line was 14 feet; above, at the broadest part of the beam 18 feet, and with the gangways added 21 feet. The space between the Diaphragmata was 7 feet.

The height of the deck in Cataphract ships above water was 11 feet. The draught, $8 \frac{1}{2}$ feet. Total height, $19 \frac{1}{2}$ feet. Thus leaving $10 \frac{1}{2}$ feet for the hold. 'I'he height of the aphract trireme from water to the top of the gunwale is calculated at 8 feet. The capacity of the Cataphract trireme, calculated according to the modern formula of measurement gives 2321 tons.

As all the Attic triremes appear to have been built on one and the same model, their gear was interchangeable. It is obvious that such an arrangement in a ficet of from 300 to 400 vessels would offer great facilities in refitting.

The regular crew of an Attic trireme consisted probably of 225 persons in all. Of these 174 were employed in rowing, disposed as follows:54 Thalamites, $58 \mathrm{Zyg}$ ites, 62 !'Thranites, the upper oars being the most numerous, as the contraction of the vessel near the bow and towards the stern afforded less space for the lower tiers. Besides the rowers, there was a force of 10 marines, heary-armed soldiers, and 20 seamen. The number of marines seems to have raried greatly, and depended much on the style of fighting preferred. Where, as in the case of the Athenians, speed and dexterity in the ase of the ram were the chief tactical features, fewer marines were employed. Xerxes' great flect carried 30 marines to each trireme. We hear of forty picked men on board each Chian vessel at Lade. The Corinthians and Corcyreans had their decks crowded at the battle of Sybota; and the unfortmnate Athenians, in the great harbour of Syracuse, where there was no space for their usual methods of manouvring, found themselves obliged to imitate their enemy's tactics in this respect, with disastrous results.

Of the officers the chief was the Trierarch or Captain, and next to him the master ( $\left.\kappa v^{3} \beta \rho \nu \eta_{i}, i s\right)$, who was responsible for the steering and sailing of the vessel. Each tier of rowers on either side had its

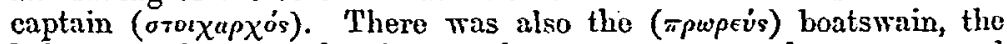
keleustes, who gave the time to the rowers, a steward, a purser, and

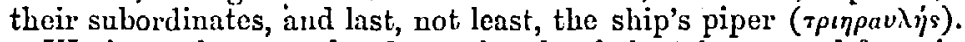

We have thus completed our sketch of the trireme, and from it we 
mas also form, without any difficulty, an idea of the larger vessels, quadriremes, quinqueremes, \&c. The principles of construction in these were exactly the same, the additional tiers being added by carrying on the Diaplingmata upwards, and at the same regular intervals inserting the thwarts on which the rowers' scats rested. The increase in the size of the whole vessel was not as large as one might at first expect. In order to aroid entering into further detail $I$ have prepared a table from Graser, which exhibits clearly the difference. The increase in the size of Greek vessels began after the Peloponnesian war, and seems to have culminated in the time of Demetrius Poliorcetes, who manourred with vessels of sixteen banks of oars, and we hear of nearly every number of banks of oars up to that figure. The huge tesseraconteres of Ptolemy Philopater, with its forty banks of oars, was in reality a costly toy, and of no practical use. A nuinute and curious description is given by Graser of this great ship, but I fear that we must not delay upon it liere.

The Romans who copied a quinquereme which fell into their hands in the first Punic War, appear to have used vessels chiefly of that description. They did, however, build much larger vessels up to the time of Actium, when the defeat of Antony and Cleopatra's great ships, by the light Liburnians, altered the whole fashion aind prepared the way for the disappearance of the great banked galleys, and the almost complete loss of the knowledge of the principle on which they were constructed.

An interesting question arises at this point, and one not easily solved, as to the pace at which these galleys could be moved. We may make a comparison between the man-power of the galley and the horse-power of the modern ship of war. The difference in the bulk to be moved is very great and the inferences derived may be misleading. T'aking, however, one horse-power to be equivalent to between 7 and 8 man-power, we may say that the trireme was propelled by a force equal in amount to about 24 horse-power, the quadrireme by about 32 horse-power, the quinquereme about 42 , and so on, increasing a little more than 10 horse-power for each tier of oars added. It is, howerer, obvious, that the man-power cannot be counted upon as applied to the oar with that uniformity which is attained by the use of steam in the case of horse-power.

There is a passage in Xenophon (Anab. vi, 42) in which it is stated that from Byzantium to Heraclea, in Bithynia, a distance of about 150 nautical miles, could be rowed in a day by a trireme, and was a very long day's work. Now, allowing eighteen hours' daylight for the work, a speed would have to be maintained of over eight knots. This, considering the shape of the vessel and the man-power employed, may perhaps seem excessive, bnt if such a speed could be maintained on an average for a whole day's vogage, it is obvious that in action or when any special effort was required, a greater pace, say perhaps 10 knots, conld be attained.

Such speed we may believe was attained, if at any time, in those famous encounters, in which the ressel itself was the missile hurled at the enemy, when, in the prime of her Thalassocracy, the rapidity 
and agility of the trireme of $\Lambda$ thens was the terror alike of her Greek and her Phocnician foes. Long and careful training had perfected the system of rowing and stecring. The vessel itself was shaped for speed by the cunning master builders of a people whose eje for form has never been surpassed. To the attainment of the highest possible speed erergthing was sacrificed, till at last the thin sharp bows were incapable of standing a concussion with the heavy mass presented to them by Corinthian and S5racusan constructors, and suffered them. selres the damage they were intended to inflict npon others.

Time will not allow me here to follow out in detail the second part of mJ snbject, the derelopment of the ram in its successire t5pes, from the sharp Assyrian spur, the old Phœnician fish-like snout, the early Greek boar's head, which we can trace down to the third cen. turr on coins, to the three tecthed rostram of the early Macedonian and later Roman epoch.

I shonld have liked, had time sufficed, to have tonched upon some of the instances of single encounters, such as those of Artemisia, and of the Samothracian vessel at Salamis, and of Phormion's Captain off Naupactus, and further, to hare pointed out the causes why the ( $\pi \rho \circ \beta \beta \lambda \eta$ ) direet attack stem-on, that, which in the eyes of the Athenian was the unskilful and unseamanlike manoenrre, prerailed

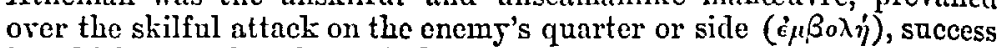
in which was the glorg of the Attic sailor; to have slown how, as Thucydides aptly calls it, "land fighting at sea" beene the rale; how grappling irons, and boarding bridges, and ponderous missiles, ultimately superseded ramming tactics to such an extent that Brutus, off Marseilles, exposed the sides of his great ressel on purpose to the enems, trusting to the thickness of his timbers, and making sure of destroying his smaller antagonists with the ponderous weight swinging from his yardarm.

Time, however, forbids me to enter upon these points; and in conclusion, if $I$ hare not already tried your patience too long with what I fear has been a somewhat dry mass of details, I would ask you to leap back with me in thonght orer long centuries of the past that we may imagine ourselres standing in the Peiræus, with the glories of Athens behind us, the great spear head of the goddess who guards the Propyliea flashing the reflected ray far across the Saronic Gulf, where in front of us lies bright Salamis, and begond, Egina, once called the eje-sore of the port in which we stand.

It is a busy bustling scene, one that would riral oar own Portsmouth and $\mathrm{Pl}$ ymouth in a time of war. There are the long sheds in which the triremes hare been housed during the winter, but they are mostly empty (for is it not April?), and the rollers on the long stone ways have run down many of the dry keclsand launched them already. It is April, 415 years before Christ, and the Athenians are preparing their fleet for their grand and fatal expedition to Sicily. They dream of conquest, of the conquest of the golden west. The triangular land is the stepping-stone to greater things bejond. Nearer home there are enemies, but ambition is stronger than fear, and we fit out our fleet and send our picked men for distant enterprises, while tho enemy is not 
very far from our own doors. And so the dockyard is all life. Look at the huge coils of hawsers, at the rows of anchors, at the stacks of oars, all carefully marked, all arranged with precision. There in the harbour are already lying some hundred sail, some few ready to start for Corcyra, but most still fitting ont with all haste. What shrill pipings, what a clatter of tongues, what a smell of pitch. Yonder goes Lamachus the busiest of the three Admirals, and the most practical. He sees to details with the eye of a master who means business, and knows that real work is grim work. Fine young Alcibiades will be down in the afternoon on a four-in-hand from town. Ho gives himself airs, but is clever and brilliant, and handsome, and with the exception of sqme old sea $\operatorname{dog} s$, hard bitten ones who mislike the smell of jockey-club and musk, and growl about effeminacy and affected manners, his subordinates like him well enough. And here comes kind well meaning Nicias, a good man, and well esteemed, but hardly the stuff for such a command, though his good fortune has been tried up to the present time and has never been found wanting. Truly it were better to die joung than to be so fortunate. And the chicfs being there the work is not slack. The hammering goes on with redoubled vigour. The petty officers have their hands full and look serious, the comptrollers of accounts are in dismay, the trierarchs are sure they will be ruined. But there is a strong will behind them all, and a nation's behest is not casily disobeyed, and fancied impossibilities both as regards time and space are reduced by hard work to possible proportions. And so the fleet is fitted out, and if we will return after a few days, we shall sce in company with all Athens, a spectacle which none will forget to his dying day, which now may draw tears of mingled pride and sorrow, pride patriotic, and sornow for those who are going away, but the recollection of which hercafter will command, alas! far more bitter tears of shame and grief; shame for country humbled, and grief foi those who will never return. There in the glorious bright blue bay, float, fully equipped, as we hare described, one hundred triremes, 60 as men of war, 40 as transports. They are to start solemnly with a nation's prajers and a nation's blessing The pennants are waving in the breeze, the acrostolia are crowned with flowers; the piper. sounds the rowers to their seats, and then silence is demanded by the long blast of the bugle from the Admiral's flag-ship, caught up and re-echoed by the ships of each of the three divisions. Then are the prayers offered and the libations poured to unwilling deities by brave hands, and hearts ignorant of the future, and the signal being forth. with given, more than 17,000 oars dash into the water together, and the whole fleet starts in one splendid trial of speed towards Egina. We strain our eyes after them until the white sails are set, and the hope and strength of Athens fares onwards out of sight, to a distant enterprise, the issue of which with all its pride and all its folly, with its glory and its misery, will adorn history, and point a moral for maritime powers in all time to come. 


\section{APPENDIX.}

Table shouing Comparative Length of Oars.

\section{Athenian Nary.}

\begin{tabular}{|c|c|c|c|c|}
\hline & Inboard. & Outboard. & Total. & Blade. \\
\hline 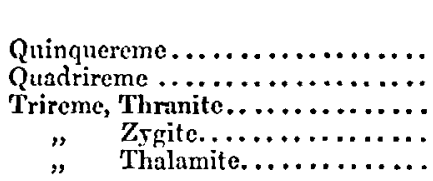 & $\begin{array}{cc}\text { ft. } & \text { in. } \\
6 & 6 \\
5 & 6 \\
4 & 6 \\
3 & 6 \\
2 & 6\end{array}$ & $\begin{array}{rr}\text { ft. } & \text { in. } \\
13 & 0 \\
11 & 0 \\
9 & 0 \\
7 & 0 \\
5 & 0\end{array}$ & $\begin{array}{rc}\text { ft. } & \text { in. } \\
19 & 6 \\
16 & 6 \\
13 & 6 \\
10 & 6 \\
7 & 6\end{array}$ & ft. in. \\
\hline
\end{tabular}

British Navy.

\begin{tabular}{|c|c|c|c|c|}
\hline & Inboard. & Outboard. & Total. & Bliade. \\
\hline $\begin{array}{l}\text { Largest } \ldots \ldots \ldots \ldots \ldots \ldots \ldots \ldots \ldots \ldots \\
\text { Medium } \ldots \ldots \ldots \ldots \ldots \ldots \ldots \ldots \ldots \ldots \\
\text { Smallest } \ldots \ldots \ldots \ldots \ldots \ldots \ldots \ldots \ldots \ldots\end{array}$ & $\begin{array}{cc}\text { ft. } & \text { in. } \\
5 & 3 \\
3 & 5 \\
2 & 6\end{array}$ & $\begin{array}{rr}\text { ft. } & \text { in. } \\
12 & 9 \\
11 & 7 \\
9 & 6\end{array}$ & $\begin{array}{cc}\text { ft. } & \text { in. } \\
18 & 0 \\
15 & 0 \\
12 & 0\end{array}$ & $\begin{array}{cc}\text { ft. } & \text { in. } \\
0 & 5 \frac{3}{4} \\
0 & 5 \frac{1}{2} \\
0 & 5 \frac{1}{4}\end{array}$ \\
\hline
\end{tabular}

Oxford University Eiglt.

\begin{tabular}{c|c|c|c|c}
\hline & Inboard. & Outboard. & Total. & Blade. \\
\hline $\begin{array}{c}\text { ft. in. } \\
38\end{array}$ & $\begin{array}{c}\text { ft. in. } \\
9\end{array}$ & $\begin{array}{c}\text { ft. in. } \\
12\end{array}$ & $\begin{array}{c}\text { ft. in. } \\
0\end{array}$ \\
\hline
\end{tabular}

Eton Eight.

\begin{tabular}{|c|c|c|c|c|}
\hline & Inboard. & Outboard. & Total. & Blade. \\
\hline $1875 \ldots \ldots \ldots \ldots \ldots \ldots \ldots \ldots$ & ${ }_{3} 6$ & $\begin{array}{ll}\text { ft. in. } \\
90\end{array}$ & $\begin{array}{l}\text { ft. in. } \\
126\end{array}$ & $\begin{array}{l}\text { ft. in. } \\
0\end{array}$ \\
\hline
\end{tabular}


Talle of Measurements, \&־., from Graser.

\begin{tabular}{|c|c|c|c|c|}
\hline Class of Vessel. & Trireme. & Quadriremc. & Quinguereme. & $\begin{array}{c}\text { Tesseracon- } \\
\text { teres. }\end{array}$ \\
\hline 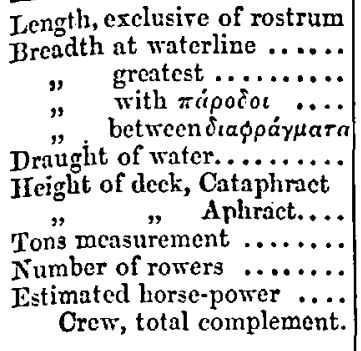 & $\begin{array}{l}149 \text { fect. } \\
14 " \\
18 " \\
21 " \\
7, \\
8 \frac{1}{2} " \\
11 " \\
8 " \\
232 " \\
174 \\
24 \\
225\end{array}$ & $\begin{array}{c}15 S_{2}^{1} \text { fect. } \\
16 " \\
22 ", \\
25 ", \\
9 \\
10 ", \\
13 " \\
10 " \\
365 " \\
2.10 \\
32 \\
300\end{array}$ & $\begin{array}{l}168 \text { feet. } \\
18 " \\
26 " \\
29 " \\
11 ", \\
11 \frac{1}{2} " \\
15 " \\
12 " \\
534 " \\
310 \\
42 \\
375\end{array}$ & $\begin{array}{r}420 \text { fect. } \\
57 " \\
76 " \\
79 " \\
49 " \\
20 " \\
41 " \\
11,320 \\
4,05.4 \\
540 \\
7,500\end{array}$ \\
\hline
\end{tabular}

$\left.\begin{array}{l}\text { Triaconter, } 51 \text { feet long, } \\ \text { Penteconter, } 90 \text { feet long, }\end{array}\right\}$ two masted.

The Crusmsax : I am sure that we all feel deeply impressed with the fact, that we hare just heard a most interesting lecture, and not only a rery interesting, but a rery learned and eloquent one, especially in the moring words with which it was concluded. But what $I$ also myself feel, and strongly feel, in consequence, is a deep regret that a more fit and competent person is not in the chair on this oceasion. For I was requested to fulfil this honour purely through haring a larger acquaintance with the localities referred to in the lecture-the scenes of the great naral battles and contests mentioned-than most of the members likely to be present.

That adrantage has undoubtedly tended greatly to enhanee the interest of the lecture with me, aud I am sure that there are some present who are likewise familiar with some of these localities, and hare felt a similar enhaneed interest.

The lecturer referred to, and recommended to your notice, Mr. Smith's book, on "The Toynge of St. Paul." Mr. Smith was an intimate friend of mine, and spent a winter in IIalta whilst I was there; and as an able geologist, he had intended, during lis stay, to work out the geologs of Malta. But, as I happened to be a mere smatterer in this branch of science, I had been induced just previously to do the same. Mr. Smith thus finding that the labour of his hope and lore had been somewhat forestalled, as he himself told me, was indueed to take up the rogage of St. Paul, from its special interest in connection with Malta. We were, therefore, frequently in communieation with regard to it, and to the construction of the ships, mode of rorring them, \&c., of the ancients of that date. Mr. Smith has in that work giren a chapter of great interest upon the form and position of the oars and rowers in the quinquiremes, triremes, \&c., as he had conceired them to be. But I must confess that, although there mas much that was new in it bearing upon the subject, yet it did not fully satisfy me that we yet understood the exact construction of the ancient Greek and Roman ships of war, so as to know how the rowers of the several tiers were placed. Now, howerer, I fully understand it, after the beautiful illustrations, and the clerer model made by the Fion boy, that has been so often in the hands of the learned lecturer during the delirery of his most instructire and most interesting discourse. I nust not, howerer, try your patience further with more remarks of my own, but at once fulfil the duty that now derolves upon me, of asking you to accord your hearty thanks to the learned lecturer for his rery instruetire and interesting lecture, and also to the Fton boy for the clerer model his talent has produced, and that has tended so much to assist the lecturer in his deseription, and ourselres in understanding the diffeult points of the subject. 